\title{
DEVELOPING A NEW COMBINATION AND PROPORTION OF CHEMICALS FOR THE PRODUCTION OF LAUNDRY DETERGENT AT LOW COST IN CONTEXT OF BANGLADESH
}

\author{
SADIA AFREEN \\ Department of Chemical Engineering \\ Bangladesh University of Engineering \& Technology, Dhaka, Bangladesh \\ Phone: 01712659929, Email milkyway9903@yahoo.com
}

This work proposes a new combination and proportion of chemicals available in the local market to prepare laundry detergent at low cost in context of Bangladesh. The proposed formula ensures good foaming and washing quality of the detergent that can compete the existing other laundry detergents in the market. The $\mathrm{pH}$ of the product is maintained at 10 which is close to that of other detergent powder being sold in market now. The cost analysis in accordance with the proposed formula shows that the production of $1 \mathrm{~kg}$ detergent powder costs 20-25 BDT; therefore, can be sold at a price lower than the other detergents available in market. The proposed formula can reduce the selling price of the detergent at 40-45 BDT, whereas the other companies are selling it from 50-140 BDT in the market. This offers a new scope to produce laundry detergent at a very low cost as well as good washing performance of the product using the locally available chemicals in Bangladesh.

\section{Keywords: Laundry Detergent, New Formula, Cost, Performance}

\section{INTRODUCTION}

Laundry detergent is widely used a household chemical product all over the world. In Bangladesh this is also popular for washing and cleaning clothes. The production of laundry detergent comprises of the combination of various chemicals. There are some common chemicals required for the production of laundry detergents. Besides these common chemicals, different industries use different types of other chemicals which are responsible for the comparative quality of detergents produced by various companies. Production of detergents includes various chemicals; of them some are costly and need to be used in right proportion for the effective performance. Some of these costly chemicals are specially imported in Bangladesh because they are not available in the local chemical market.

Laundry detergents are formulated from six groups of substances:

\section{. Surfactants \\ . Builders \\ . Bleaching-agents \\ . Enzymes \\ . Fillers}

Besides these common ingredients, some other components are added like, corrosion inhibitors, brightener, etc to upgrade the detergent's quality. The combination and proportion of the components used in the preparation of laundry detergent may vary. Besides some common compounds various other chemicals are available to formulate a new and effective detergent recipe. This work presents a new and effective formula for laundry detergent having good washing and cleaning properties, at a price lower than the others available in market

\section{PRESENT SCENARIO}

A survey on the present scenario shows that the chemicals used by the industries to produce laundry detergent differ to a great extent. Some are using sodium sulphate as the major ingredient and some are Calcium Carbonate. Some are using special ingredient like enzyme for the better efficiency of their product. The following table shows the chemicals used by the industries producing laundry detergent in Bangladesh.

Table 1: Chemicals Used by Different Industries in Bangladesh

\begin{tabular}{|c|c|}
\hline Industry Name & $\begin{array}{c}\text { Chemicals Used in } \\
\text { Detergent }\end{array}$ \\
\hline Surf Excel & $\begin{array}{c}\text { LASAD, Sodium } \\
\text { Carbonate, STPP, SCMC, } \\
\text { Enzyme, Tinopol CBSX, } \\
\text { Tinopol DMSX }\end{array}$ \\
\hline Wheel Lemon Powder & $\begin{array}{c}\text { Sodium LAS, Soda Ash, } \\
\text { Calcium Carbonate, CI } \\
\text { 74240, CI 11680, } \\
\text { Perfume }\end{array}$ \\
\hline Wheel Rin Power White & $\begin{array}{c}\text { Sodium LAS, Sodium } \\
\text { Carbonate, SCMC, } \\
\text { Perfume, Tinopol CBSX, }\end{array}$ \\
\hline
\end{tabular}




\begin{tabular}{|c|c|}
\hline & Tinopol DMSX \\
\hline Keya White Plus & Sodium LAS, Sodium \\
& Carbonate, Zeolite, \\
& Tinopol CBSX, SCMC, \\
& Colored Bentonite, \\
& Perfume, Aqua \\
\hline Keya Lemon Detergent & Sodium LAS, Sodium \\
& Carbonate, Calcium \\
& Carbonate, Color, \\
& Perfume \\
\hline Chaka Washing Powder & Dolomite Powder, Soda \\
& Ash Light, Sodium \\
& Sulphate, LABSA, Aqua, \\
& Perfume, CI 74260 \\
\hline Kohinoor & LABSA, Soda ah, \\
& Precipitated Calcite, \\
& Sodium Sulphate, \\
& Perfume \\
\hline
\end{tabular}

\section{METHODOLOGY}

Experiments have been conducted in several trials. Chemicals have been collected from the local chemical market situated at Mitford, Dhaka. The $\mathrm{pH}$ and other physical properties of the chemicals were tested individually in the laboratory. After each trial of detergent preparation the $\mathrm{pH}$, foaming, washing and cleaning quality have been tested to find out the best result. Detergent proportion and composition were tested in several trials for one $\mathrm{kg}$ basis of the major ingredient Sodium Sulphate. Cost analysis has been done for each trial to understand the commercial feasibility of the detergent and finally the best trial has been proposed to formulate the detergent powder.

\section{PROPOSEED COMBINATION AND PROPORTION OF DETERGENT}

The laboratory test has found that the following composition and proportion of chemicals offer a good quality detergent;

$\begin{array}{lr}\text { Sodium Sulphate } & 1000 \mathrm{~g} \\ \text { Sodium Carbonate } & 22.22 \mathrm{~g} \\ \text { Tinilon } & 6.06 \mathrm{~g} \\ \text { Texapon } & 4.44 \mathrm{~g} \\ \text { LABSA } & 5.26 \mathrm{~g}\end{array}$

Sodium Sulphate is used here as the major ingredient of the detergent powder. It can perform as filler which enables the adjustment of the active matter in the detergent to the doses used. Sodium carbonate is added here as builder. Builders are water softeners.
These chemical compounds are agents that remove calcium ions by complexation or precipitation. They function by sequestering or precipitating the problematic ions. Linear alkyl benzene sulphonic acid or LABSA is included as a surface active agent. It is a low cost surfactant for detergent and has good surface active properties. Texapon has an outstanding cleaning and detergency property. Because of its good foam characteristics and easy thickening with salt it also performs as a surfactant here. Tinilon is used additionally as a good foaming agent for the detergent powder.

\section{PERFORMANCE TEST RESULT}

The performance test has been done with some clothes having dirt and stains on them. A small amount of detergent (approximately $20 \mathrm{gm}$ ) is dissolved in a bucket of water and the clothes are kept in it for 20 minutes. After 20 minutes the clothes are taken out from the detergent water to observe the washing and cleaning performance of the formulated detergent powder. The observation has shown that the stains and dirt have been removed successfully from the clothes by using the formulated detergent powder. The overall performance test of the formulated detergent has shown the following result:

$$
\text { Foam Quality: Well }
$$

Cleaning and Washing Performance: Good

$$
\text { pH: } 10
$$

The $\mathrm{pH}$ of detergent is generally maintained at 10 or close to 10 . The $\mathrm{pH}$ test of some other detergent powder available in the market shows the following result:

Table 2: $\mathrm{pH}$ of other detergents available in market

\begin{tabular}{|c|c|}
\hline Name of the Detergent & pH \\
\hline Wheel Power White & 10 \\
\hline Keya Lemon Powder & 10 \\
\hline Wheel Lemon Powder & 10 \\
\hline Surf Excel & Close to 10 \\
\hline
\end{tabular}

\section{COST ANALYSIS}

To attain the commercial feasibility of the formulated detergent powder the individual price of the detergent chemicals available in the local market has been surveyed. The cost for the preparation of about one $\mathrm{kg}$ detergent is then determined. The present market price of the detergent chemicals is given here: 
Table 3: Market price of the chemicals available for the production of detergent

\begin{tabular}{|c|c|}
\hline Chemical & Cost \\
\hline Sodium Sulpate & 18 \\
\hline Sodium Carbonate & 35 \\
\hline LABSA & 150 \\
\hline $\begin{array}{c}\text { Sodium Lauryl Sulphate/ } \\
\text { Tinilon }\end{array}$ & 480 \\
\hline Fluroscent Brightener & 130 \\
\hline STPP & 120 \\
\hline Emulsifying Agent & 480 \\
\hline Calcium Carbonate & 32 \\
\hline CMC & 120 \\
\hline Tinopol & 200 \\
\hline Dolomite & 20 \\
\hline Texapon & 300 \\
\hline Wetting agent & 350 \\
\hline Super Wheel Scent & 1200 \\
\hline
\end{tabular}

The detail of the cost analysis for the proposed formula of detergent is given in the following table. Calculations have been done for $1 \mathrm{~kg}$ basis of Sodium Sulphate as the major ingredient of the product. All the calculations are based on the present (2011) market price of the available chemicals.

Basis: $1 \mathrm{~kg}$ Sodium Sulphate

Table 4: Cost Analysis of the Proposed Formula

\begin{tabular}{|c|c|c|c|}
\hline Ingredients & $\begin{array}{c}\text { Cost/kg } \\
\text { (BDT) }\end{array}$ & $\begin{array}{c}\text { Proposed } \\
\text { Amount (gm) }\end{array}$ & $\begin{array}{l}\text { Cost for } \\
\text { the } \\
\text { Proposed } \\
\text { Amount } \\
\text { (BDT) }\end{array}$ \\
\hline $\begin{array}{c}\text { Sodium } \\
\text { Sulphate }\end{array}$ & 18 & 1000 & 18 \\
\hline $\begin{array}{c}\text { Sodium } \\
\text { Carbonate }\end{array}$ & 35 & 22.22 & 0.78 \\
\hline LABSA & 150 & 5.26 & 0.79 \\
\hline Tinilon & 480 & 6.06 & 2.91 \\
\hline Texapon & 300 & 4.44 & 1.33 \\
\hline \multicolumn{2}{|c|}{ Total } & $\begin{array}{c}1037.98 \\
\text { (approximately } \\
1 \text { kg detergent } \\
\text { powder) }\end{array}$ & 23.81 \\
\hline
\end{tabular}

The price of other detergent powder available in market is shown in the following table:
Table 4: Comparative Price of the Laundry Detergent Powder

\begin{tabular}{|c|c|}
\hline Detergent Powder & $\begin{array}{c}\text { Cost/kg } \\
\text { (BDT) }\end{array}$ \\
\hline Wheel Lemon Powder & 58 \\
\hline Wheel Rin Power White & 74 \\
\hline Keya White Plus & 52 \\
\hline Chaka Washing Powder & 54 \\
\hline Surf Excel & 140 \\
\hline Kohinoor Detergent & 52 \\
\hline Keya Lemon Powder & 52 \\
\hline
\end{tabular}

The production of approximately $1 \mathrm{~kg}$ detergent powder costs almost 24 BDT. Considering other additional costs involved in the production, the selling price of $1 \mathrm{~kg}$ detergent powder produced from the proposed formula can be set from $40-45$ BDT, whereas the others are selling from 50 to 100 and more.

\section{SCOPE OF ADVANCE WORK}

At present days, enzymes are getting popular as an active ingredient of detergent. The enzymes used in laundry detergents act on materials that make up a variety of stains and soils so that these materials can be washed away more easily. These enzymes are named after the materials they can act upon, for example, proteases break down protease based stains, lipolases break down lipid (fat) based stains and amylases break down starches and other carbohydrate based stains. Since one enzyme molecule can act on many substrate molecules, a small amount of enzyme added to laundry detergent can provide a big cleaning benefit to the consumers. But the cost of enzyme is high and imported in Bangladesh since there is no local manufacturer of enzyme. For this reason the local manufacturers of detergent powder in Bangladesh cannot use enzyme to enhance the quality of their detergent. Only big companies like, Unilever is found using effective enzyme in their detergent product named Surf Excel.

The invention or development in manufacturing enzymes from local resources can bring more scope to the production of effective laundry detergent in Bangladesh to compete the international market of laundry detergent. A good example of resources is Papaya. Papaya, especially unripe ones, is a great source of Papain enzyme. This enzyme is useful to remove protease type stains from the clothes. In developed countries high technology is being used to extract Papain enzyme from Papaya and use it commercially. Future work can be proposed in this area with a target to invent a cost effective manufacturing process of detergent enzyme from the 
available local resources to enhance the washing quality of the formulated detergent.

\section{CONCLUSION}

Like all other countries, Bangladesh also has large consumption of laundry detergent. But the problem faced in this sector is, some of the chemicals are not available in the local market throughout the year. Big companies like Unilever, Square are used to import chemicals independently rather buying them from the local market. This is also a cause for the high selling price of detergent here. If the proposed formula is used commercially, it can offer new scope of work as well as change the present scenario.

\section{REFERENCES}

1. Fariha Hasan, Amir Ali Shah, Javed and Hameed (2010), Enzymes used in detergents: Lipases, African journal of biotechnology, vol 9(31), pp 4836-4844.

2. Khaparde SS and Singhal RS (2001), Chemically Modified papain for applications in detergent formulations.

3. Mohammad Farhat Ali and James G.Speight, Mcgraw Hill Handbooks, Handbook of Industrial Chemistry: Organic Chemicals, Chapter-5: Soap and Detergents.

4. Unilever Detergent's Power Plant, Pavilion Technologies

5. Azad Chemicals, Suppliers of detergent chemicals, Momtaz Market, Midford Road, Dhaka-1100

6. Kamrul chemical and perfsumery suppliers, Momtaj Market, Midford Road, Dhaka-1100 